\title{
Estimating South Cascade Glacier (Washington, U.S.A.) mass balance from a distant radiosonde and comparison with Blue Glacier
}

\author{
L. A. Rasmussen, H. Conway \\ Geophysics Program, Box 351650, University of Washington, Seattle, Washington 98195-1650, U.S.A.
}

\begin{abstract}
A simple flux model using twice-daily measurements of wind, humidity and temperature from standard upper-air levels in a distant radiosonde estimated winter balance of South Cascade Glacier, Washington, U.S.A., over 1959-98 with error 0.24 m w.e. Correlation between net and winter balance is strong; the model estimates net balance with error $0.53 \mathrm{~m}$ w.e. Over the past 40 years, average net balance of South Cascade Glacier has been strongly negative $(-0.46 \mathrm{~m}$ w.e.), and it has been shrinking steadily. In comparison, $200 \mathrm{~km}$ west-southwest at Blue Glacier, the average balance has been less negative $(-0.13 \mathrm{~m}$ w.e.); that glacier has undergone little change over the 40 years. Balance histories of the two glaciers are positively correlated $(r=+0.54)$, and South Cascade has been more out of balance than Blue, presumably because it is still adjusting to climate change since the Little Ice Age. Recent warming and drying has made the net balance of both glaciers strongly negative since 1976 ( $-0.84 \mathrm{~m}$ w.e. at South Cascade, $-0.56 \mathrm{~m}$ w.e. at Blue). If South Cascade Glacier were in balance with the 1986-98 climate, it would be about one-quarter of its present area.
\end{abstract}

\section{INTRODUGTION}

The principal objective of this study is to investigate the use of radiosonde measurements in estimating glacier mass-balance components by using a simple moisture-flux model. Several characteristics of the components are also analyzed: correlation of annual values with seasonal values, the vertical profile of mass balance including interannual variability of the profile, and trends of the mass-balance components and relevant climate variables over the past 50 years. Differences and similarities between the responses of South Cascade and Blue Glaciers, Washington, U.S.A., over this period are analyzed.

\subsection{Need for analysis of accumulation}

Owing to practical considerations, measurements of glacier ablation are generally much more abundant than those of accumulation, both as to the number of glaciers and as to the frequency during the season. Ablation is usually measured several times during the ablation season at a small number of stakes. Accumulation is measured, usually only at the end of the accumulation season, by probing the thickness of residual snow at a large number of sites and determining its density at a smaller number of sites, sometimes only one. In most models of glacier mass balance, accumulation is represented either by a synthetic database (e.g. Oerlemans, 1992) or by extrapolating precipitation and surface temperature from nearby weather stations (e.g. Greuell, 1992).

Determination of the amount of accumulation requires knowledge of both the total amount of precipitation and the temperature at which it falls, so that snow can be distinguished from rain. Because of the covariance of temperature and precipitation in the northwest U.S.A., the monthly mean temperature is not a good indicator of the rain-snow

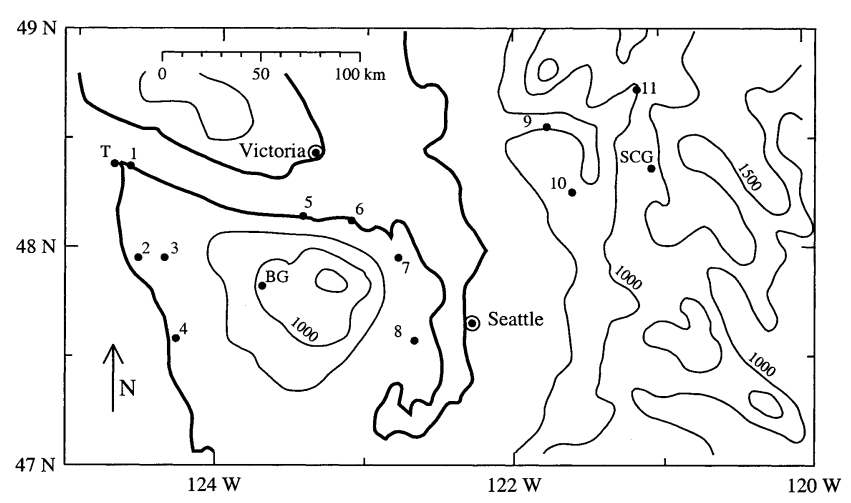

Fig. 1. Northwestern Washington state with weather stations (solid circles), Blue Glacier (BG), South Cascade Glacier (SCG), other stations identified in Table 1. The radiosonde was at Tatoosh Island (T) prior to 1 August 1966 and at Quillayute (2) afterward. Elevation contours (interval $500 \mathrm{~m}$ ) are for topography smoothed over about $15 \mathrm{~km}$. The heavy curve is the smoothed coastline.

split of the monthly total precipitation; in addition, applying a vertical lapse rate to temperatures measured at lowland stations does not give as good an estimate of temperature at higher elevation as does using upper-air measurements from radiosondes (Rasmussen and others, 2000).

\subsection{South Gascade Glacier}

South Cascade Glacier $\left(48.36^{\circ} \mathrm{N}, 121.06^{\circ} \mathrm{W}\right)$ is a small, northfacing, temperate glacier on the crest of the North Cascade Range of northwestern Washington, $250 \mathrm{~km}$ from the Pacific Ocean (Fig. 1). It has an elevation range of 1630-2130 $\mathrm{m}$ and an area of $2.0 \mathrm{~km}^{2}$. Most precipitation on the glacier falls as 
snow, with $\approx 3 \mathrm{~m}$ w.e. accumulating each winter at the head of the glacier. Annual ablation at the terminus usually exceeds $8 \mathrm{~m}$ w.e. The glacier is not in equilibrium with the recent climate, having retreated strongly and lost much mass over the past century (Miller, 1969; Krimmel, 1999).

\subsection{Blue Glacier}

Blue Glacier $\left(47.82^{\circ} \mathrm{N}, 123.70^{\circ} \mathrm{W}\right)$ is a small, north-facing, temperate glacier in the Olympic Mountains of northwestern Washington, $55 \mathrm{~km}$ from the Pacific Ocean (Fig. 1). It has an elevation range of $1275-2350 \mathrm{~m}$ and an area of $4.3 \mathrm{~km}^{2}$. Most precipitation on the glacier falls as snow, with $\approx 4 \mathrm{~m}$ w.e. accumulating each winter at the head of the glacier. The glacier has been roughly in equilibrium with the recent climate, having changed little over the past 60 years in either thickness or areal extent (Conway and others, 1999).

\subsection{Data sources}

The U.S. Geological Survey established a research program at South Cascade Glacier in the mid-1950s. Values of winter balance and net balance for each year, both averaged over that year's glacier topography, have been determined annually since 1958 (Krimmel, 1999). Winter balance is measured near the end of the accumulation season by probing the snow depth at numerous points spanning the elevation range of the glacier and converting the depth to its water content by using an elevation variation of density obtained from direct measurements at usually one or two elevations. Net balance is measured at the end of the ablation season by using the previous summer surface as the reference. In early years, balance was measured at several stakes in holes drilled into the ice, in later years at a smaller number of stakes in positions learned in the early years to be strategic for determining the elevation variation over the whole glacier. For each year 1986-98, vertical profiles of both winter balance and net balance, along with meteorological measurements and glacier topography, are published in Krimmel (1993, 1994, 1995, 1996, 1997, 1998, 1999, 2000), which in this paper are referred to collectively as RMK. Mass-balance values for 1986-91 in earlier RMK were revised in Krimmel (2000).

The University of Washington established a research program at Blue Glacier in the mid-1950s. Net balance has been estimated by various methods for each year since 1955 (LaChapelle, 1965; Armstrong, 1989; Conway and others, 1999). In early years, balance was measured at several stakes in holes drilled into the ice on the lower glacier and by probing late-summer snow on the upper glacier. In later years, net balance was estimated from the correlation observed in the early years between it and the equilibrium-line altitude (ELA) late in the ablation season, which has been observed each year since then. The time series of net balance has been adjusted to be consistent with topographic maps made in 1957 and 1987, along with laser altimetry in 1996. There have been few determinations of either the seasonal components of mass balance or its vertical profile.

The U.S. National Weather Service operated a radiosonde station with twice-daily soundings from 1948 until 1 August 1966 at Tatoosh Island, $275 \mathrm{~km}$ west of South Cascade Glacier, and since then at Quillayute, about $50 \mathrm{~km}$ south and $10 \mathrm{~km}$ east of Tatoosh Island (Fig. 1). The radiosonde data, archived by the U.S. National Climatic Data Center, have been reformatted for distribution by the U.S. National Center for Atmospheric Research. Soundings usually measure tempera- ture, humidity and wind at many levels in the atmosphere, but measurements at only $850 \mathrm{mbar}(\approx 1450 \mathrm{~m})$ and $700 \mathrm{mbar}$ $(\approx 3000 \mathrm{~m})$ are used in this analysis.

U.S. National Weather Service personnel and volunteers have measured precipitation and temperature at numerous stations in the region, with records at many stations extending back to the early 20th century. These are published monthly by state in summaries titled Climatological Data, catalogued under ISSN 0364-5320.

\section{REGIONAL GLIMATOLOGY}

Northwestern Washington has mild, wet winters and mild, dry summers. The four wettest months, November-February, account for about $57 \%$ of the annual precipitation, and the four driest months, June-September, for only about $11 \%$. Nearly all precipitation in this region (Fig. 1) is produced by extratropical cyclones from the Pacific Ocean, often occurring in rapid succession in winter and only occasionally in summer. Convective storms are uncommon, even in summer. The north-south-trending Cascade Range is an effective climate barrier that separates the humid marine region to the west from the arid continental region to the east.

Precipitation has high coherence, therefore, although with strong spatial gradients: lowland sites annually receive $>3 \mathrm{~m}$ on the west side of the Olympic Peninsula, $<0.5 \mathrm{~m}$ on the lee side, and intermediate amounts elsewhere. Correlation of October-April precipitation with that at Forks, on the west side of the peninsula, follows the same high-low pattern (Table 1). So does the small number of June-September wet days, which is consistent with summer precipitation coming from large storms.

At the elevation of glaciers, precipitation is about 1.5 times that at nearby lowland stations. Most precipitation falls as snow in winter and rain in summer, but exceptions occur in both seasons. Some winter rain refreezes, eliminating a shallow cold wave having built up in the surface layer of the glacier during earlier cold, clear weather (LaChapelle, 1958). Summer snowfalls are usually slight and soon melt.

Conway and others (1995) found that temperature measured at $2008 \mathrm{~m}$ on Blue Glacier is much better approximated by interpolating at that elevation in the nearby Quillayute radiosonde than by applying an assumed lapse rate to tem-

Table 1. Climatological stations

\begin{tabular}{lrrrr}
\hline \multicolumn{1}{c}{ Station } & $z$ & $\bar{P}$ & $r$ & $n$ \\
\hline 1. Neah Bay & 3 & 2.4 & 0.85 & 94 \\
2. Quillayute & 55 & 2.2 & 0.95 & 94 \\
3. Forks & 107 & 2.6 & 1.00 & 92 \\
4. Clearwater & 23 & 2.6 & 0.88 & 93 \\
5. Port Angeles & 30 & 0.5 & 0.77 & 107 \\
6. Sequim & 55 & 0.3 & 0.51 & 108 \\
7. Chimacum & 43 & 0.6 & 0.64 & 103 \\
8. Bremerton & 49 & 1.1 & 0.77 & 104 \\
9. Concrete & 59 & 1.5 & 0.84 & \\
10. Darrington & 168 & 1.7 & 0.90 & \\
11. Diablo Dam & 272 & 1.6 & 0.76 & 96 \\
& & & & \\
\hline
\end{tabular}

Notes: Station number shows location in Figure 1 (stations listed west to east); elevation $z$ is in meters, $\bar{P}$ is mean October-April precipitation in meters, $r$ is correlation of October-April precipitation with Forks, and $n$ is mean number of June-September days with $P<2 \mathrm{~mm}$ (Fig. 7), an indicator of atmospheric transmittance and thus of solar radiation. Statistics over 1959-98. 


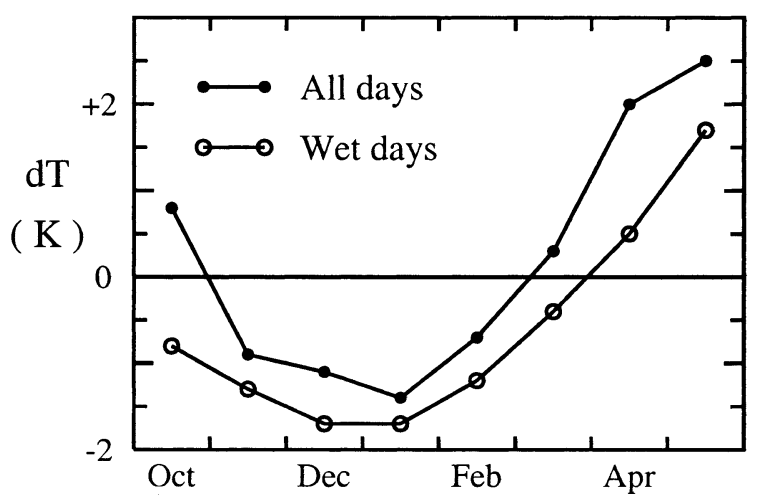

Fig. 2. Temperature difference between South Cascade Glacier and radiosonde at monthly resolution. Wet-day values are the difference between temperatures measured at the glacier at $1848 \mathrm{~m}$ and interpolated at $1848 \mathrm{~m}$ between the 850 and 700 mbar levels in the radiosonde on days in 1994-97 when precipitation occurred at the glacier. All-day values were scaled from monthly 850 mbar charts (United States Navy, 1966), averaged over all days in the month. The temperature difference between the glacier and the radiosonde is assumed to apply over the entire elevation range of the glacier.

perature at a nearby lowland station. South Cascade Glacier, however, is five times as far from the radiosonde, and temperatures measured on wet days there in 1994-97 (RMK) showed substantial, seasonally varying differences $\Delta T(t)$ from those interpolated at the same elevation in the radiosonde. Because temperature is used here only to determine precipitation phase, temperatures were compared (Fig. 2) only on days when $\geq 2 \mathrm{~mm}$ was measured at the glacier. The glacier-radiosonde difference $\Delta T$ is assumed to be constant over the elevation range of the glacier.

For comparison, the seasonal variation of the glacierradiosonde temperature difference at 850 mbar was scaled from an upper-air atlas (United States Navy, 1966), which showed that the temperature gradient swings from southsouthwest in winter to east-southeast in summer and doubles in magnitude. Both curves (Fig. 2) reflect the seasonal swing of the gradient, but the wet-day curve is systematically more negative, indicating a greater glacier-radiosonde difference than on all days, which the upper-air atlas represents. The difference between the wet-day and all-day curves is comparable to that at 850 mbar in the radiosonde itself (Rasmussen and others, 2000, fig. 3). The projection of the gradient on the line between Tatoosh Island and Quillayute, however, is nearly constant through the year, with Quillayute about $0.3 \mathrm{~K}$ warmer, which was used to adjust the Tatoosh Island observations to create a time series more homogeneous with the Quillayute observations.

\section{ESTIMATING SOUTH CASGADE GLACIER WINTER BALANGE}

Snowfall at South Cascade Glacier is estimated from a variation of the moisture-flux model developed by Rasmussen and others (2001). When applied to Forks (Fig. 1) over 194896 , the model estimated total precipitation with coefficient of determination $r^{2}=0.50$ for daily amounts and $r^{2}=0.84$ for monthly amounts. Using values of basic variables only at standard upper-air levels makes the model suitable for use with meteorological databases of historical conditions or output from circulation models representing postulated future climates.

\subsection{Snow-flux model}

Precipitation at the glacier is assumed to be proportional to the moisture flux $F$ at the $850 \mathrm{mbar}$ level at the radiosonde station and is estimated from measurements of the wind and humidity by the relation

$$
F(t)=\left\{\begin{array}{cc}
U \mathrm{RH} & (U \geq 0) \\
0 & \text { (otherwise) }
\end{array}\right.
$$

in which $0 \leq \mathrm{RH} \leq 1$ is the relative humidity, and $U$ is the component of the 850 mbar wind in the empirically determined critical direction $\phi^{\prime}$. That is,

$$
U=\left|\vec{V}_{850}\right| \cos \left(\phi_{850}-\phi^{\prime}\right),
$$

where $\phi_{850}$ is its direction and $\left|\vec{V}_{850}\right|$ is its speed in meters per second.

The precipitation is assumed to fall as snow $f(z, t)$ at a particular elevation $z$ and time $t$ if the temperature less than the critical temperature $T^{\prime}$

$$
f(z, t)=\left\{\begin{array}{cc}
F(t) & \left(T(z)+\Delta T(t) \leq T^{\prime}\right) \\
0 & \text { (otherwise) }
\end{array}\right.
$$

in which $T(z)$ is the temperature in the radiosonde, $\Delta T(t)$ with monthly resolution (Fig. 2) is the mean difference between the glacier and the radiosonde, and $T^{\prime}=+2{ }^{\circ} \mathrm{C}$ is the rain-snow discriminator (Oerlemans, 1993; Rasmussen and others, 2000).

The snow flux over the season ending on 8 May in year $j$ is taken to be the average over the $k$ twice-daily soundings from 1 October of year $j-1$ through 8 May of year $j$.

$$
\bar{f}_{j}(z)=\frac{1}{k} \sum_{1 \text { Oct }}^{8 \text { May }} f(z, t) .
$$

The autumn date is chosen as the standard beginning of the water year in this region, and the spring date as the mean over 1986-98 of the dates on which the winter balance was measured (RMK). Depending on whether or not year $j$ is a leap year, $k$ is either 440 or 442 .

The glacier's winter balance is estimated from

$$
b_{\mathrm{w}, j}^{*}=\alpha(z) \bar{f}_{j}(z)+\beta(z),
$$

in which $\alpha(z)$ and $\beta(z)$ are chosen to minimize the rms error between the 40 estimates $b_{\mathrm{w}, j}^{*}$ and observed winter balances $b_{\mathrm{w}, j}$ for the 40 balance years $j=1959,1960, \ldots, 1998$. It is given by

$$
\mathrm{rms}=\left[\frac{1}{40} \sum_{j}\left(b_{\mathrm{w}, j}^{*}-b_{w, j}\right)^{2}\right]^{1 / 2},
$$

and the coefficient of determination is

$$
r^{2}=1-\left(\frac{\mathrm{rms}}{\sigma}\right)^{2}
$$

in which $\sigma$ is the standard deviation of the observed values.

\subsection{Results}

Mean seasonal snow flux $\bar{f}$ at $z=1650 \mathrm{~m}$ gives the best fit (Equation (5)) to observed winter balances, with $\mathrm{rms}=$ 0.24 mw.e. and $r^{2}=0.85$. The goodness of fit gradually declines as $\bar{f}$ at higher $z$ are used, with $\mathrm{rms}=0.28$ and $r^{2}=$ 0.80 at $2150 \mathrm{~m}$. Snowfall at lower $z$ is always accompanied by snowfall over the entire glacier, whereas snowfall at higher $z$ is sometimes accompanied by rain at lower $z$. The decline is 


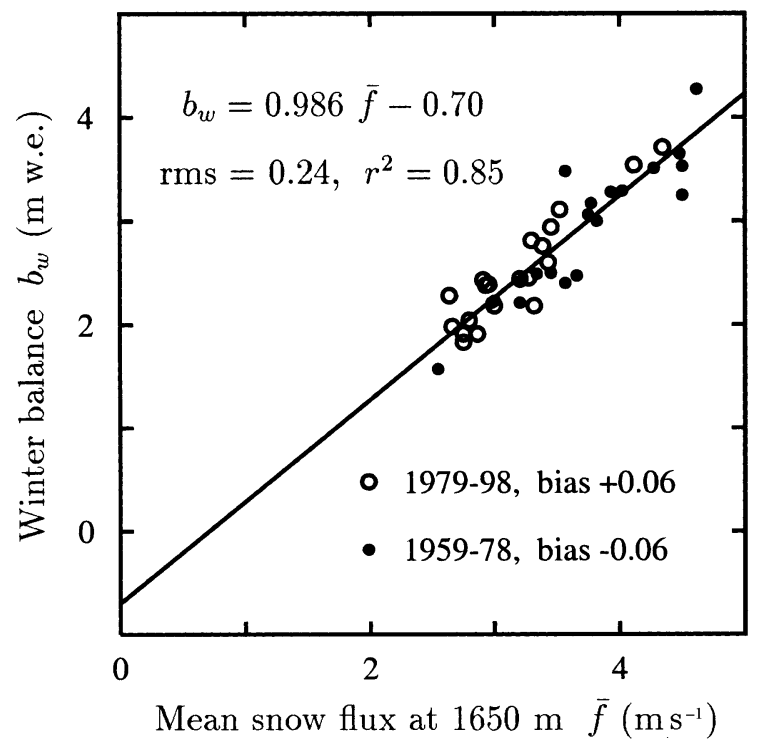

Fig. 3. Model results for South Cascade Glacier, using critical direction $\phi^{\prime}=263^{\circ}$ in Equation (2) and $z=1650 \mathrm{~m}$ in Equation (3) over 1959-98. The line (Equation (5)), with coefficients $\alpha=0.986$ and $\beta=-0.70$, has $\mathrm{rms}=$ 0.24 mw.e. and $r^{2}=0.85$. Residuals for 1959-78 (solid circles) have mean value -0.06 , and for 1979-98 (open circles) have mean value +0.06 .

gradual because the snow flux is so strongly correlated at any two elevations (the correlation with the flux at $1650 \mathrm{~m}$ is still $r^{2}=0.94$ at $2150 \mathrm{~m}$ ) because most storms that deposit snow do so over the entire glacier. High correlation of the snow flux at two elevations prevents a multiple regression using snow flux at two elevations from giving appreciably better results than using just the $1650 \mathrm{~m}$ flux.

Coefficients of the $1650 \mathrm{~m}$ fit (Fig. 3), $\alpha=0.986$ and $\beta=$ -0.70 , reflect the composition of the winter balance: a positive accumulation component and a negative ablation component. If accumulation is assumed to be proportional to the snow flux, $\alpha$ accounts for the scale factor between them, and $\beta$ accounts for ablation during the accumulation season. Standard errors in the coefficients are $\sigma_{\alpha}=0.067$ and $\sigma_{\beta}=0.23$.

The optimum critical direction $\phi^{\prime}=263^{\circ}$ is nearly normal to the mean trend of the Cascade Mountains, whereas for stations on the west side of the Olympic Peninsula it is $238^{\circ}$ (Rasmussen and others, 2001), which is the direction of maximum moisture flux in this region. That study showed the nearly circular range of the Olympic Mountains to exert only a secondary influence on the optimum critical direction because flow can go around them. By contrast, it cannot go around the long, linear barrier of the Cascades, so the up-slope effect of flux normal to that barrier apparently overrides the importance of the direction of the maximum source of moisture. The Olympic Mountains themselves are a deterrent to South Cascade Glacier receiving flux along $\phi^{\prime}=238^{\circ}$ because they lie roughly in that direction from the glacier (Fig. 1).

Interannual variation of the mean seasonal snow flux $\bar{f}(z)$ is due in almost equal parts to that in the number $n_{\mathrm{f}}$ of soundings with flux $f(z, t)>0$ (Equation (3)) and to that in the mean intensity $\bar{f}^{\prime}(z)$ of those $n_{\mathrm{f}}$ fluxes. At $1650 \mathrm{~m}$ over the 40 years, $n_{\mathrm{f}}$ varied between 207 and 309 soundings, with mean 260 and standard deviation 26, while $\bar{f}^{\prime}(z)$ varied between 4.86 and $6.82 \mathrm{~m} \mathrm{~s}^{-1}$, with mean 5.80 and standard deviation 0.52. Thus, the coefficient of variation (ratio of the standard deviation to the mean) was about the same for $n_{\mathrm{f}}(0.10)$ as for $\bar{f}^{\prime}(z)(0.09)$. Over the 40 years, the mean intensity of those fluxes $\bar{f}^{\prime}(z)$ has correlation $r=+0.51$ with the number of them $n_{\mathrm{f}}$. Years with more wet days, therefore, generally have wetter wet days.

\subsection{Model residuals}

There are several sources of error in the snow-flux-balance fit, Equation (5). The model crudely represents the relevant physical processes and coarsely samples atmospheric conditions: two vertical levels at one geographic point. Measurement of humidity is notoriously difficult compared with other radiosonde observations, has undergone changes of method over the years and has been subject to archiving irregularities (Rasmussen and others, 2001, section 4). Measurement of winter balance is subject to sampling error in the horizontal, using imprecise density values, and the possibility of not probing exactly to the previous summer surface.

An inconsistency exists between the variables in the snow-flux-balance fit. Snow flux is strictly a climate variable, but glacier total winter-balance values describe the effect of climate on a varying glacier topography. Balance curves $b_{\mathrm{w}}(z)$ integrated over a fixed topography give different values from those obtained by integrating them over an evolving topography. The published values were integrated year by year over a topography that was steadily losing area at low elevation, where the winter balance is less positive than at higher elevation. The published values for the early years are less positive, and for the later years more positive, than they would have been had their $b_{\mathrm{w}}(z)$ been integrated over the mean 1959-98 topography. This effect is reflected by the distribution (Fig. 3) of residuals from Equation (5), with those over 1959-78 having a bias of $-0.06 \mathrm{~m}$ w.e. and those over 1979-98 having a bias of $+0.06 \mathrm{~m}$ w.e. A separate estimate of the effect of the topographic variation over the entire 40 year period can be obtained by inserting a time term into the fit

$$
b_{\mathrm{w}, j}^{*}=\alpha(z) \bar{f}_{j}(z)+\gamma t+\beta(z),
$$

in which $t$ is measured in years from the beginning of the period. For $z=1650 \mathrm{~m}$, it has optimum direction $\phi^{\prime}=$ $264^{\circ}, \alpha=1.034, \gamma=0.007$ and $\beta=-0.96$. It fits the data only slightly better than Equation (5), with $\mathrm{rms}=0.23$ and $r^{2}=$ 0.86 , reflecting the stronger effect of other error sources.

\subsection{Model stability}

The model parameters are strongly orthogonal, with the apparent optimum value of one being relatively insensitive to the values adopted for the others. For instance, the choice of level $z$ used in fitting the winter balance had negligible effect on the apparent optimum value of the critical direction $\phi^{\prime}$. Raising $U$ to a power in Equation (1) had little effect on the apparent optimum value of $\phi^{\prime}$, as did imposing constraints on $U$ or RH. Because $T$ and $z$ are so closely related through the vertical lapse rate $\left(\approx 6 \mathrm{~K} \mathrm{~km}^{-1}\right)$, varying the rain-snow discriminator $T^{\prime}=+2^{\circ} \mathrm{C}$ would be roughly equivalent to using $\bar{f}$ at another $z$. The horizontal temperature gradient $\Delta T(t)$ was not adjusted as a model parameter.

A variant of Equation (1) in which the vapor pressure $e$ is used in place of $\mathrm{RH}$ has rms 0.29 for optimum critical direction $\phi^{\prime}=264^{\circ}$ with coefficients $\alpha=0.210$ and $\beta=-1.00$. The $\mathrm{RH}$ variant is better presumably because it expresses the nearness to saturation regardless of temperature, whereas $e$ at a particular $\mathrm{RH}$ varies strongly with temperature, roughly doubling between $T=-5^{\circ} \mathrm{C}$ and $T=+5^{\circ} \mathrm{C}$. 
A variant in which $U$ is used alone in Equation (1) has rms 0.28 for $\phi^{\prime}=258^{\circ}$ with coefficients $\alpha=0.801$ and $\beta=-0.78$, which performs so well because of the high correlation between RH and wind direction, with moist onshore flow accompanying a westerly wind.

Split-sample tests show that the critical direction $\phi^{\prime}$ and the regression coefficients $\alpha$ and $\beta$ are highly stable. The RH model (Equation (1)) calibrated on only the even-numbered years had $\phi^{\prime}=258^{\circ}$ with coefficients $\alpha=0.923$ and $\beta=$ -0.70 , which when applied to the even-numbered years gave rms 0.28 . The model calibrated on only the odd-numbered years had $\phi^{\prime}=264^{\circ}$ with coefficients $\alpha=1.056$ and $\beta=$ -0.84 , which when applied to the even-numbered years gave rms 0.26 .

Narrowing the sector from which flux is calculated does not improve the results. That is, when Equation (2) is written

$$
U=\left|\vec{V}_{850}\right| \cos \left[\psi\left(\phi_{850}-\phi^{\prime}\right)\right]
$$

for $\psi>1$, it has the effect of using only those $\phi_{850}$ from a narrower interval around $\phi^{\prime}$. The optimum values over the 40 years are $\psi=1.08$ and $\phi^{\prime}=258^{\circ}$, which give $r^{2}$ only 0.001 greater than using $\psi=1$.

\subsection{Relation of vertical profiles of snow flux and observed winter balance}

The regression Equation (5) relates the glacier average winter balance to the snow flux at a single elevation but does not determine a vertical profile of estimated winter balance. Winter balance is the sum of accumulation $c_{\mathrm{w}}$ and ablation $a_{\mathrm{w}}$ components

$$
b_{\mathrm{w}}(z)=c_{\mathrm{w}}(z)+a_{\mathrm{w}}(z),
$$

of which the snow flux corresponds only to $c_{\mathrm{w}}$.

The existence of substantial ablation at South Cascade Glacier between 1 October and 8 May is indicated by the marked curvature in the measured $b_{\mathrm{w}}(z)$ over 1986-98 (Fig. 4), as well as by the regression constant $\beta$ in Equation (5) being significantly negative. Not only is there usually sufficient energy to melt October snowfalls, but ice melt often continues into October at low elevations (RMK). Over 1986-96, October was warmer $\left(4.5^{\circ} \mathrm{C}\right)$ than April $\left(1.3^{\circ} \mathrm{G}\right)$ at $1615 \mathrm{~m}$ (RMK). Although the average albedo is much lower in October, when the lower glacier is often snow-free, the Sun is $18^{\circ}$ higher in April, so the absorbed radiation might also be appreciable in spring.

In any particular year $j$, in the absence of independent information about ablation, $b_{\mathrm{w}}(z)$ could be estimated from $b_{\mathrm{w}, j}^{*}$ by assuming accumulation is proportional to $\bar{f}_{j}(z)$

$$
c_{\mathrm{W}}(z)=\mu \bar{f}_{j}(z)
$$

and using the average $a_{\mathrm{W}}(z)$ obtained from the 1986-98 $b_{\mathrm{w}}(z)$. Equation (10) must integrate over the extent of the glacier to match the estimate $b_{\mathrm{w}, j}^{*}$ from Equation (5)

$$
\begin{aligned}
\int b_{\mathrm{w}}(z) \mathrm{d} z & =\int c_{\mathrm{w}}(z)+a_{\mathrm{w}}(z) \mathrm{d} z \\
& =\mu \int \bar{f}_{j}(z)+a_{\mathrm{w}}(z) \mathrm{d} z=b_{\mathrm{w}, j}^{*}
\end{aligned}
$$

which determines the coefficient $\mu$ from the profiles $\bar{f}_{j}(z)$ and $a_{\mathrm{w}}(z)$.

A parametric family of ablation curves $a_{\mathrm{w}}(z)$ can be inferred from the observed balance $b_{\mathrm{w}}(z)$ over 1986-98, in which the parameter is the amount of winter ( 1 October-8 May) ablation at the top of the glacier. Three curves $a_{\mathrm{w}}(z)$ corres-

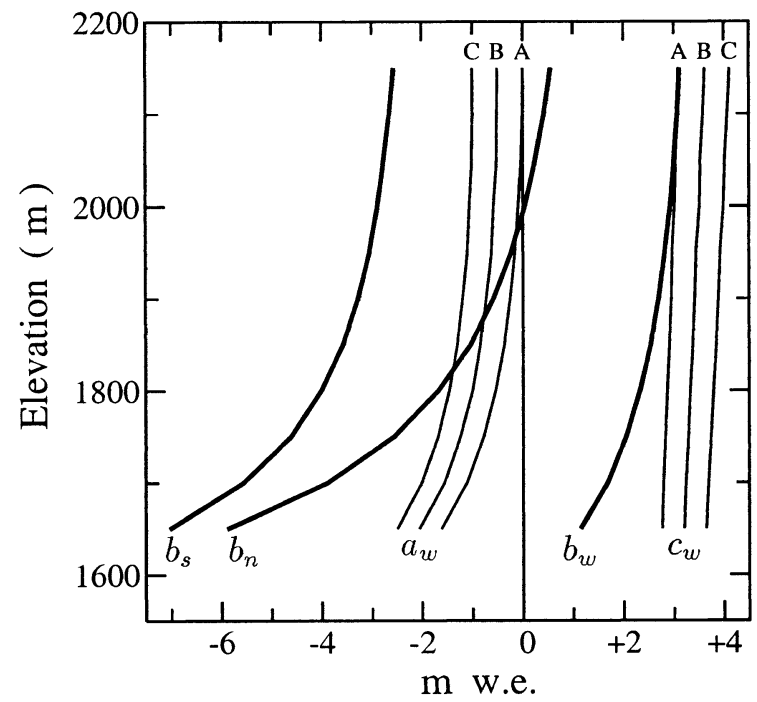

Fig. 4. Observed winter balance $b_{\mathrm{w}}(z)$ at South Cascade Glacier and three sets of accumulation $c_{\mathrm{w}}(z)$ and ablation $a_{\mathrm{w}}(z)$ curves consistent with it through Equation (10). The curves have $a_{\mathrm{w}}(2150)$ equal to $0(A),-0.5 \mathrm{~m}$ (B) and $-1.0 \mathrm{~m}$ (C). Curves for $c_{\mathrm{w}}(z)$ from Equation (11) are averages over 1986-98 for $\mu=0.84,0.98,1.11$, using critical direction $\phi^{\prime}=$ $263^{\circ}$ in Equation (2) and Equation (3) over 1 October-8 May. Also shown is summer balance $b_{\mathrm{s}}(z)$, which is obtained by subtracting $b_{\mathrm{w}}(z)$ from the observed net balance $b_{\mathrm{n}}(z)$.

ponding to $a_{\mathrm{w}}(2150)=0,-0.5,-1 \mathrm{~m}$ are shown in Figure 4. The total ablation integrated over the 1992 glacier topography for these three cases is, respectively, $-0.33,-0.80,-1.27 \mathrm{~m}$ w.e., and the corresponding $\mu$ values are $0.84,0.98,1.11$. Although $\mu$ and the total ablation are not precisely the same quantities as the regression coefficients $\alpha$ and $\beta$ (Equation (5)), the values for the $a_{\mathrm{w}}(2150)=-0.5 \mathrm{~m}$ case are similar to them, with $a_{\mathrm{w}}(1650)$ $=-2.1 \mathrm{~m}$ w.e. at the terminus. R. M. Krimmel (personal communication, 2000) favors the case with no winter ablation at the top of the glacier (Fig. 4, curve A), which has $\mu=0.84$ and $-1.6 \mathrm{~m}$ w.e. ablation at the terminus.

\section{ESTIMATING NET BALANGE}

\subsection{Correlation with summer and winter balances}

South Cascade Glacier is consistent with the observation (Dyurgerov and Meier, 1999) that the net balance of glaciers in maritime climates correlates about the same with summer balance as with winter balance, whereas for glaciers in continental climates it correlates better with summer balance. Over the 40 years 1959-98, the net balance had correlation $r_{\mathrm{nw}}=+0.79$ with the winter balance and $r_{\mathrm{ns}}=$ +0.73 with the summer balance. The summer-balance values, which here are defined to be negative, were obtained as the difference between the winter balances and net balances given in RMK.

For any mass-balance record, the two seasonal correlations depend on only two quantities: (1) the correlation $r_{\mathrm{ws}}$ between $b_{\mathrm{w}}$ and $b_{\mathrm{s}}$, and (2) the ratio $\lambda=\sigma_{\mathrm{w}} / \sigma_{\mathrm{s}}$ of their standard deviations. The following results are the special case $c_{1}=c_{2}=1$ of the easily derived statistics of a linear combin- 
ation $z=c_{1} x+c_{2} y$ of random variables $x$ and $y$ (Bevington, 1969, p. 64).

$$
\begin{aligned}
\left(\begin{array}{c}
r_{\mathrm{nw}} \\
r_{\mathrm{ns}}
\end{array}\right) & =\frac{1}{\sigma_{\mathrm{n}}}\left(\begin{array}{c}
\sigma_{\mathrm{w}}+r_{\mathrm{ws}} \sigma_{\mathrm{s}} \\
\sigma_{\mathrm{s}}+r_{\mathrm{ws}} \sigma_{\mathrm{w}}
\end{array}\right) \\
& =\frac{1}{\sqrt{\lambda^{2}+2 r_{\mathrm{ws}} \lambda+1}}\left(\begin{array}{c}
\lambda+r_{\mathrm{ws}} \\
\lambda r_{\mathrm{ws}}+1
\end{array}\right),
\end{aligned}
$$

in which the three standard deviations are related by $\sigma_{\mathrm{n}}^{2}=\sigma_{\mathrm{w}}^{2}$ $+2 r_{\mathrm{ws}} \sigma_{\mathrm{w}} \sigma_{\mathrm{s}}+\sigma_{\mathrm{s}}^{2}$. Dyurgerov and others (1989) expressed the relations between the correlations and standard deviations in graphical form. The inverse is

$$
r_{\mathrm{ws}}=r_{\mathrm{nw}} r_{\mathrm{ns}}-\sqrt{\left(1-r_{\mathrm{nw}}^{2}\right)\left(1-r_{\mathrm{ns}}^{2}\right)}
$$

and

$$
\lambda=\sqrt{\frac{1-r_{\mathrm{ns}}^{2}}{1-r_{\mathrm{nw}}^{2}}} .
$$

The 1959-98 statistics for South Cascade Glacier are $\sigma_{\mathrm{n}}=$ $0.89, \sigma_{\mathrm{w}}=0.61, \sigma_{\mathrm{s}}=0.55, \lambda=1.11$, and $r_{\mathrm{ws}}=+0.16$. Dyurgerov and Meier (1999) found that 36 of 50 Northern Hemisphere glaciers had positive correlation $r_{\mathrm{ws}}$ (although they defined $b_{\mathrm{s}}$ to be a positive quantity, so that in their analysis the 36 values were negative) and they classified the 14 exceptions as "very special cases". Positive correlation is thought to result from high albedo persisting longer into the ablation season following heavy winter accumulation, rather than from correlation between winter and summer meteorological conditions.

Because of the strong $r_{\mathrm{nw}}$, the model (section 3.1) estimates $b_{\mathrm{n}}$ with $r^{2}=0.65$ and $\mathrm{rms}=0.53 \mathrm{~m}$ w.e. When $\phi^{\prime}=263^{\circ}$ is used in Equation (2) and $\bar{f}$ at $z=1650 \mathrm{~m}$ is used along with $b_{\mathrm{n}}$ in Equation (5), its coefficients are $\alpha=1.250$ and $\beta=-4.81$.

\subsection{Parametric family of balance curves for individual years}

Net balance curves $b_{\mathrm{n}}(z)$ and winter balance curves $b_{\mathrm{w}}(z)$ at South Cascade Glacier for each of the 13 years 1986-98 (RMK) permit investigating whether they can be better represented as a parametric family

$$
b_{j}(z)=\bar{b}(z)+\Delta b_{j},
$$

as suggested by Meier and Tangborn (1965), or as a parametric family

$$
b_{j}(z)=\bar{b}\left(z+\Delta z_{j}\right),
$$

which is equivalent to raising or lowering the equilibrium line. Here $b_{j}(z)$ is the balance curve $b_{\mathrm{n}}(z)$ or $b_{\mathrm{w}}(z)$ for year $j$, and $\bar{b}(z)$ is its 13 year mean.

The rms over $1700 \leq z \leq 2050 \mathrm{~m}$ of the $b_{\mathrm{n}}(z)$ curves was 0.32 for the $\Delta b_{j}$ method and was 0.52 for the $\Delta z_{j}$ method. For winter balance $b_{\mathrm{w}}(z)$, the two values were 0.13 and 0.36 , respectively. For summer balance $b_{\mathrm{s}}(z)$, which was obtained by subtracting the $b_{\mathrm{n}}(z)$ and $b_{\mathrm{w}}(z)$ curves, the values were 0.35 and 0.39 . These values are all in $m$ w.e.

The mean $\bar{b}(z)$ curves for all three (Fig. 4) reveal why the $\Delta z$ method does not capture the variation at South Cascade Glacier as well as the $\Delta b$ method does. Because the curves approach a limiting value at high elevation, particularly $b_{\mathrm{w}}(z)$, no $\Delta z$ can reach high enough values to accommodate a highly positive year, whereas $\Delta b$ can do so directly. In the limiting case that the curves $b(z)$ for some glacier are linear, both methods would give exact results for all years. At South Cascade Glacier, it is the curvature at high elevation that severely hampers the $\Delta z$ method. Another difficulty with the $\Delta z$ method is the need, in abnormal years, either to extrapolate outside the elevation range of measurements or to apply it over only a subset of the range.

These results are consistent with calculations by Oerlemans and Hoogendorn (1989) showing that the $\Delta b$ method does better for glaciers with large interannual variations of accumulation, and that the $\Delta z$ method does better for glaciers with large interannual variations of ablation. Precipitation perturbations usually vary weakly with elevation, but ablation perturbations usually vary strongly. At South Cascade Glacier in the 10 years between 1986 and 1998 when $b_{\mathrm{n}}$ was measured over a large elevation range (RMK), the vertical gradient of the net balance $\mathrm{d} b_{\mathrm{n}} / \mathrm{d} z$ is positively correlated $(r=+0.44)$ with the glacier average net balance $b_{\mathrm{n}}$. The gradient is generally weaker in negative balance years, which is the opposite of the expected effect of strong ablation producing strong vertical gradients. This may be because negative balance years at South Cascade Glacier are the result of light accumulation rather than strong ablation.

\section{TRENDS}

Trends are examined here in terms of a step discontinuity superposed on a time series assumed to be stationary both in the stage before the discontinuity and in the stage after it; that is, a piecewise-constant function is fit to the series. The best-fitting constant in a stage of a series is the mean of the values in that stage. The time of a discontinuity between one stage and the next is determined empirically to give the best overall fit, subject to the constraint that neither stage can be $<5$ years long. Time series of mass balance and climatological variables are approximated by two-stage functions over 1958-98, which can be interpreted as a section of the five-stage functions Minobe (1997, fig. 1-c) fit to several climatological variables over 1870-1990, or of the four-stage function Rasmussen and others (2000, fig. 9) fit to the Blue Glacier accumulation estimated over 1914-96.

\subsection{Glacier mass balance}

At South Cascade Glacier (Fig. 5) the discontinuity in both net balance $b_{\mathrm{n}}$ and winter balance $b_{\mathrm{w}}$ is between 1976 and 1977, whereas for summer balance $b_{\mathrm{S}}$ it is between 1986 and 1987, reflecting the slightly greater influence $b_{\mathrm{w}}$ has on $b_{\mathrm{n}}$ compared with that $b_{\mathrm{s}}$ has (section 4.1). The 1976-77 discontinuity is consistent with the results of both Minobe (1997) and Rasmussen and others (2000), as well as with those of Ebbesmeyer and others (1991) who divided each of 40 time series of environmental variables into two stages: 1968-75 and 197784. Those three studies either analyzed records that ended too early to permit detection of the 1986-87 discontinuity or analyzed only winter conditions. Hodge and others (1998) showed that the discontinuities in $b_{\mathrm{w}}$ and $b_{\mathrm{s}}$ are significant at the $99 \%$ level according to four statistical tests.

Mass-balance values in RMK, like those published for most glaciers, embody the combined effect of climatic conditions and glacier topography. If a hypothetical glacier that is in equilibrium with its climate experiences a shift of climate, it will eventually achieve equilibrium with the new climate; in the interim, however, it will have massbalance anomalies of the same sign as the climate shift. Progressive loss of low-elevation area at South Cascade Glacier induces a growing positive effect on all three balance components $b_{\mathrm{n}}, b_{\mathrm{w}}$ and $b_{\mathrm{s}}$ compared with what they would be 


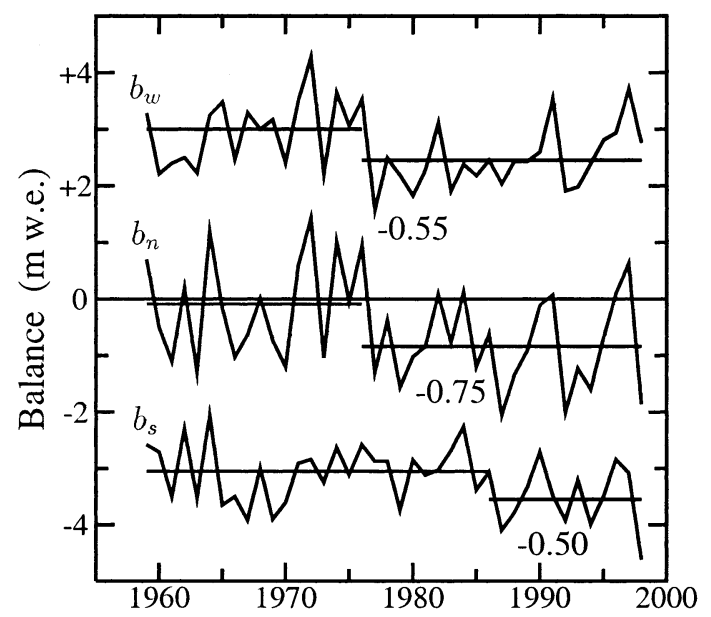

Fig. 5. South Cascade Glacier mass-balance time series ( RMK). Annual resolution. The time of discontinuity of each best-fitting piecewise-constant function is determined empirically with jumps as indicated: for winter balance $b_{\mathrm{w}}$ and net balance $b_{\mathrm{n}} 1976$-77, for summer balance $b_{\mathrm{s}}$ 1986-87.

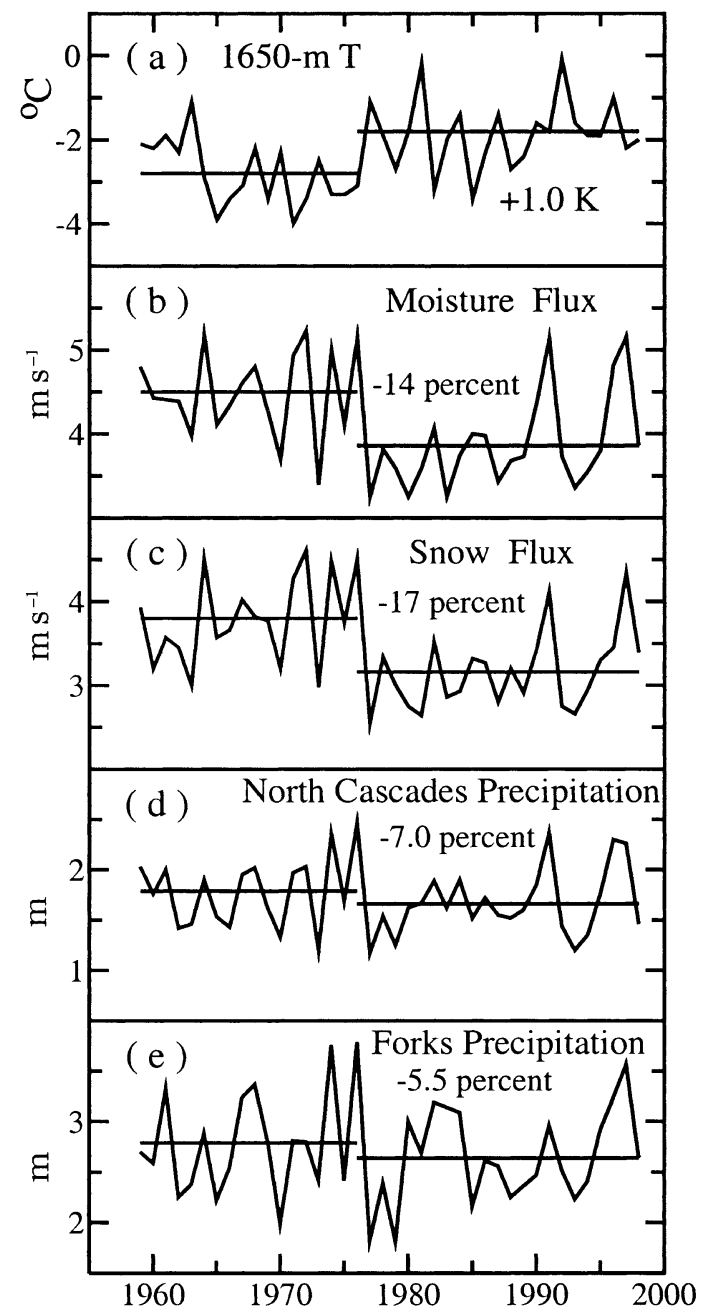

Fig. 6. Climatological time series, October-April. Annual resolution. Discontinuities of the best-fitting piecewise-constant functions, all 1976-77, were determined empirically with jumps as indicated. (a) Temperature at $1650 \mathrm{~m}$ in radiosonde on days when Forks had $\geq 2 \mathrm{~mm}$ precipitation; (b) moisture flux $F$ from Equation (1) with $\phi^{\prime}=263^{\circ}$ in Equation (2); (c) snow flux $\bar{f}$ from Equation (4) with $z=1650 \mathrm{~m}$ in Equation (3); (d) precipitation average of Concrete, Darrington and Diablo Dam; (e) Forks precipitation. Averages over 1 October-8 May ( $a-c)$, October-April (d,e).

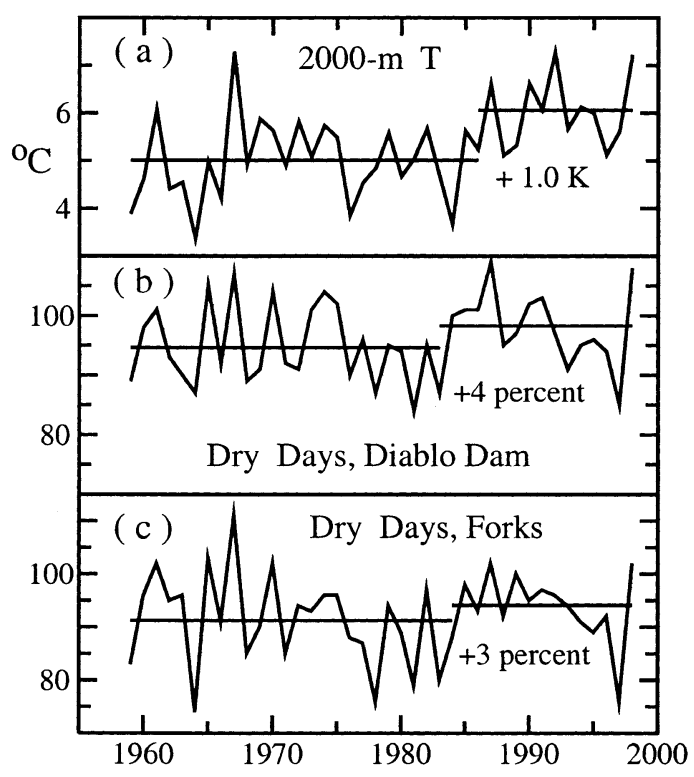

Fig. 7. Climatological time series, June-September. Annual resolution. Discontinuities of the best-fitting piecewise-constant functions were determined empirically with jumps as indicated. (a) Temperature at $2000 \mathrm{~m}$ in radiosonde, 1985-86; (b) number of days when Diablo Dam precipitation was $<2 \mathrm{~mm}$, 1983-84; (c) number of days when Forks precipitation was $<2 \mathrm{~mm}, 1984-85$.

were the balance curves $b(z)$ integrated over a fixed topography. The effect on $b_{\mathrm{w}}$ is estimated (section 3.3) as $\approx 0.007 \mathrm{~m} \mathrm{a}^{-1}$, and is cumulative; that is, after 13 years it would have an impact of nearly $0.1 \mathrm{ma}^{-1}$ on the $b_{\mathrm{w}}$. When the $b_{\mathrm{n}}(z)$ for the individual years 1986-98 are integrated over the $1992 Z(x, y)$, they indicate a departure from the values integrated over each year's $Z(x, y)$ that is about twice as large as that for $b_{\mathrm{w}}(z)$. This effect of changing topography is smaller than the magnitude of the jumps at the discontinuities: the effect is slightly positive, and the jumps are strongly negative. The time series in Figure 5 are not adjusted for this effect.

\subsection{Glimatological variables}

Over 1 October-8 May, warming at $1650 \mathrm{~m}$ (the level at which the snow flux correlates best with $b_{\mathrm{w}}$ ) and drying both have a discontinuity between 1976 and 1977 (Fig. 6). The warming is consistent with winter and spring warming of the order of $0.1 \mathrm{~K} \mathrm{a}^{-1}$ over 1973-93 throughout the troposphere over western North America found by Ross and others (1996). The primary effect of winter warming is on the rain-snow partition of precipitation; the snow fraction of the precipitation at $1650 \mathrm{~m}$ decreased from 0.84 to 0.82 after 1976. Precipitation decreased both at Forks and at stations near South Cascade Glacier, as did that implied by the $263^{\circ}$ moisture flux.

Warming at $2000 \mathrm{~m}$ (which is the approximate average ELA at South Cascade Glacier over 1986-98) and drying, both over June-September, have discontinuities in the mid1980s (Fig. 7). The number of summer dry days is an indication of atmospheric transmittance $\tau$, and thus of received solar radiation. Midday radiation measurements at $2010 \mathrm{~m}$ on Blue Glacier on 84 days in summer 1990 were used to estimate $\tau$ as a function of precipitation. A simple model setting $\tau=0.80$ when Forks had $<2 \mathrm{~mm} \mathrm{~d}^{-1}$ precipitation and $\tau=$ 0.44 when it had $\geq 2 \mathrm{~mm} \mathrm{~d}^{-1}$ approximated the values from the measurements with $r^{2}=0.60$. 


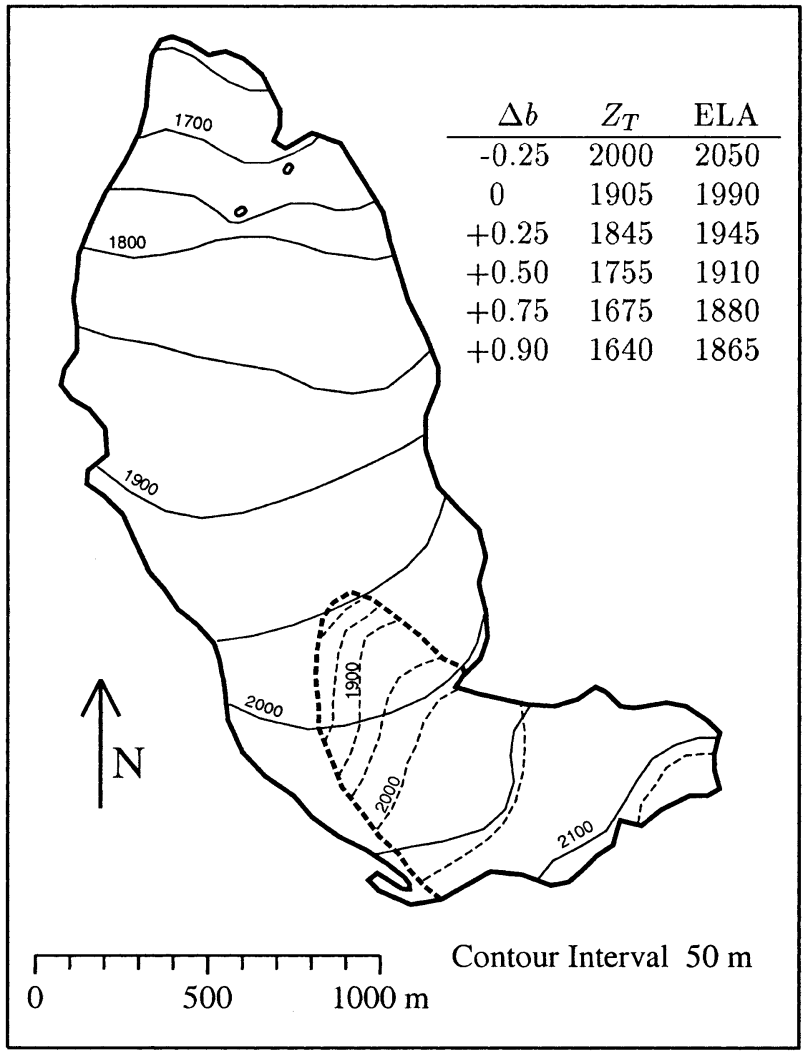

Fig. 8. South Cascade Glacier surface topography, 6 October 1992 ( solid line), from Krimmel (1993), and possible topography (dashed) in equilibrium with mean 1986-98 massbalance distribution $\bar{b}_{\mathrm{n}}(z)(R M K)$. The table shows the lower-elevation $Z_{\mathrm{T}}$ of the 1992 topography over which $\bar{b}_{\mathrm{n}}(z)$ integrates to zero when perturbed by the increment $\Delta b$ in Equation (17), as well as the ELA of the perturbed $\bar{b}_{\mathrm{n}}(z)$.

McCabe and Fountain (1995) attribute the decrease in $b_{\mathrm{w}}$ to warming and drying caused by a shift of atmospheric circulation resulting in less moisture transport from the Pacific Ocean, as shown by their analysis of the 700 mbar height field over the north Pacific and western North America. Trenberth (1990) identified intensifying of the Aleutian low as a prominent feature of the shift. Hodge and others (1998) found significant correlations between $b_{\mathrm{w}}$ and four different measures of large-scale patterns of atmospheric circulation and of sea-level temperatures; the strongest correlations were for conditions 4 months earlier in the north Pacific and 8 months earlier in the tropical Pacific, although the latter correlation appears to have broken down over the past 10 years.

\subsection{South Gascade Glacier equilibrium topographies}

Integrating the mean 1986-98 net balance $\bar{b}_{\mathrm{n}}(z)$ over the glacier topography $Z(x, y)$ indicates that it would need to be shifted (Equation(15)) by $\Delta b=+0.88$ for the 1992 topography to be in equilibrium with it (Fig. 8). The lower-elevation $Z_{\mathrm{T}}$ from which $Z(x, y)$ up to the head of the glacier $(2130 \mathrm{~m})$ defines a topography in equilibrium with $\bar{b}(z)+\Delta b$ is a function of $\Delta b$; that is, over the extent of the glacier above $Z_{\mathrm{T}}$,

$$
\int \bar{b}(z)+\Delta b \mathrm{~d} z=0 \quad\left(Z_{\mathrm{T}} \leq z \leq 2130 \mathrm{~m}\right) .
$$

These surfaces, formed by truncating the $1992 Z(x, y)$ at $Z_{\mathrm{T}}$, are mathematically in equilibrium with $\bar{b}(z)+\Delta b$ but they are not reasonable glacier topographies. For the unperturbed case, for instance, the glacier could not possibly ter-

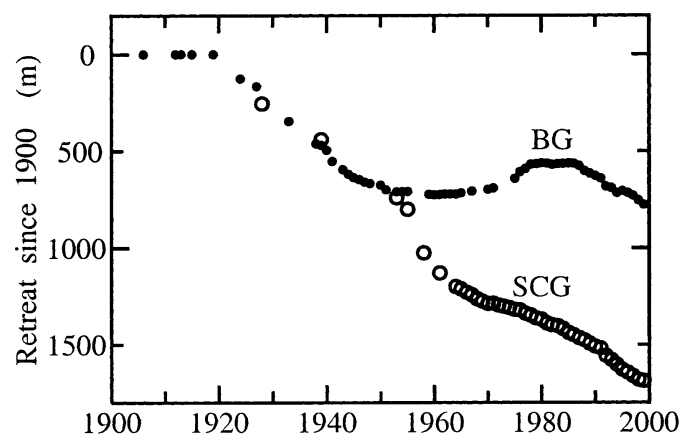

Fig. 9. Terminus retreat since 1900. Blue Glacier curve (BG) from Conway and others (1999, table 6). South Cascade Glacier curve (SCG) from R. M. Krimmel (personal communication, 2001).

minate at $1905 \mathrm{~m}$ on the $1992 Z(x, y)$ because the terminus would be a $200 \mathrm{~m}$ cliff (Hodge, 1979). Taking the surface down to the bed where the $1992 Z(x, y)=1905 \mathrm{~m}$ would make the integral more negative, so a glaciologically reasonable topography would have its terminus even farther up the valley. One such $Z(x, y)$ has its terminus at $\approx 1800 \mathrm{~m}$, which is $\approx 150 \mathrm{~m}$ below the 1992 surface (Fig. 8), delimiting a glacier with area $\approx 0.55 \mathrm{~km}^{2}$. Retreat of the terminus from its 1992 position to the equilibrium position in Figure 8 would not be inconsistent with the unrelenting retreat over the past 100 years (Fig. 9).

\section{COMPARISON WITH BLUE GLAGIER}

Differences between the mass-balance histories of South Cascade and Blue Glaciers (Fig. 1) have been the subject of much interest. Armstrong (1989) speculated that they might be due to "variations in the large-scale weather patterns between maritime and more continental locations" in the region. McClung and Armstrong (1993) describe the two histories as "radically different". The principal climatic difference between the two glaciers is that it is much drier in winter and slightly warmer in summer at South Cascade Glacier, but this does not explain why South Cascade Glacier has been more out of balance than Blue Glacier over the past 40 years.

It is not possible to make a direct comparison of seasonal mass-balance components for the two glaciers since long $b_{\mathrm{w}}$ and $b_{\mathrm{s}}$ series do not exist for Blue Glacier, but precipitation records at lowland stations provide indirect evidence of possible climate changes affecting those components. Records at Forks and near South Cascade Glacier both show winter drying since 1976 (Fig. 6d and e), suggesting declining $b_{\mathrm{w}}$. Both records also show an increase in the number of dry summer days since the mid-1980s (Fig. 7b and c), suggesting more received solar radiation and hence more negative $b_{\mathrm{s}}$. Both changes are detrimental to net balance $b_{\mathrm{n}}$ and, according to this small sample of climatological variables, both changes are slightly stronger at South Cascade than at Blue Glacier.

There is a pronounced difference in the cumulative net balance $b_{\mathrm{n}}$ for the two glaciers (Fig. 10), and it begins before the onset of those climate changes. Cumulative balance curves for both glaciers are rapidly becoming more negative since the mid-1970s, but more strongly so at South Cascade Glacier. A zero-order difference between the two curves can be expressed by adding $+0.35 \mathrm{~m}$ to each year's $b_{\mathrm{n}}$ for South Cascade Glacier, which is shown by the light curve in 


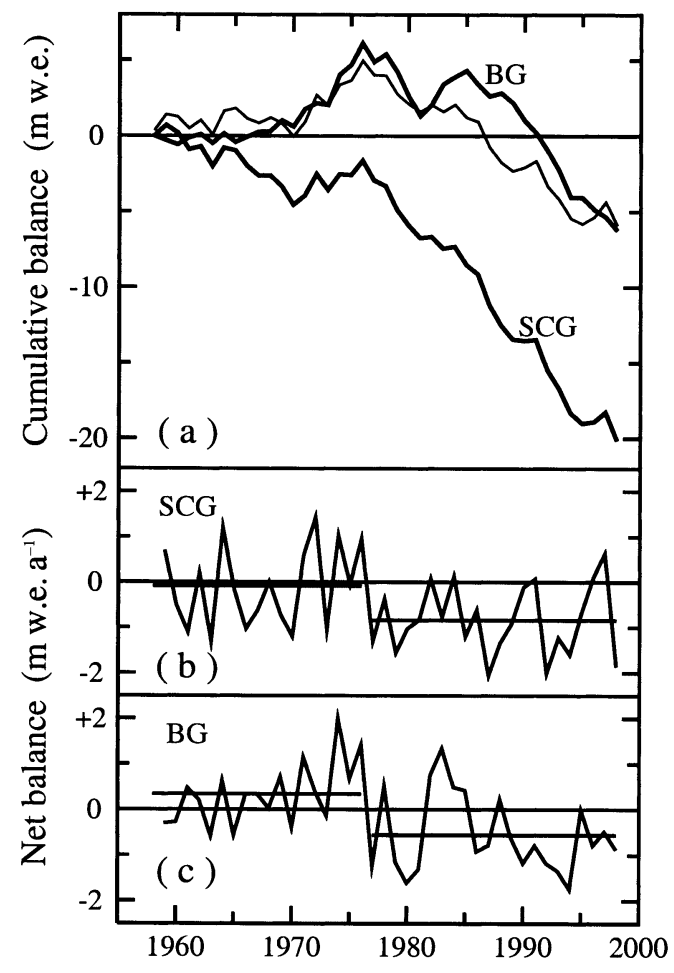

Fig. 10. Net balance: cumulative curves and piecewise-constant functions best-fitting annual values. (a) The Blue Glacier curve (BG) is the $b_{2}$ series from Conway and others (1999). The South Cascade Glacier curve (SCG) is from values in $R M K$. The light curve is formed by adding $0.35 \mathrm{~m}$ w.e. to the South Cascade Glacier values for each year. (b) South Cascade Glacier annual values, with averages -0.09 m w.e. over 1959 76 and -0.84 m w.e. over 1977-98. (c) Blue Glacier annual values, with averages $+0.34 \mathrm{~m}$ w.e. over $1959-76$ and $-0.56 \mathrm{~m}$ w.e. over 1977-98.

Figure 10. In the context of much uncertainty about the Blue Glacier balance history (Conway and others, 1999), the difference between the cumulative $b_{\mathrm{n}}$ for the two glaciers is not substantial, apart from the systematic $+0.35 \mathrm{~m}$ differential. The correlation $r$ over 1959-97 between the annual values of $b_{\mathrm{n}}$ at the two glaciers is +0.54 and is unaffected by adding 0.35 to the South Cascade Glacier $b_{\mathrm{n}}$. This is comparable to the $r=+0.55$ McClung and Armstrong (1993) obtained over the earlier period 1959-85 (although they misinterpreted it as pertaining to a 3 year lag because they did not properly align the two time series, which began in 1959 at South Cascade Glacier and in 1956 at Blue Glacier).

A likely reason for the systematic difference between the two glaciers is that by the mid-1950s Blue Glacier had already worked through most of its adjustment to the end of the Little Ice Age, whereas South Cascade Glacier still has not. Blue Glacier has not retreated significantly since the mid-1950s; moreover, strongly positive mass balance from 1959 to 1975 (Fig. 10) resulted in a $150 \mathrm{~m}$ advance during the late $1970 \mathrm{~s}$ (Fig. 9). In contrast, although the period of positive mass balance in the 1970s at South Cascade Glacier (Fig. 10) resulted in a slowing of retreat, the general pattern of ongoing retreat since 1900 (Fig. 9) indicates that it has been far from equilibrium. Comparison of the length histories (Fig. 9) and proglacial topographies (Fig. 11) shows that South Cascade Glacier was about $1600 \mathrm{~m}$ longer but its terminus was only $50 \mathrm{~m}$ lower in 1900, whereas Blue Glacier was $700 \mathrm{~m}$ longer and its terminus was $1200 \mathrm{~m}$ lower than at present. The ELA is $\approx 150 \mathrm{~m}$ higher at South Cascade Glacier, but the difference

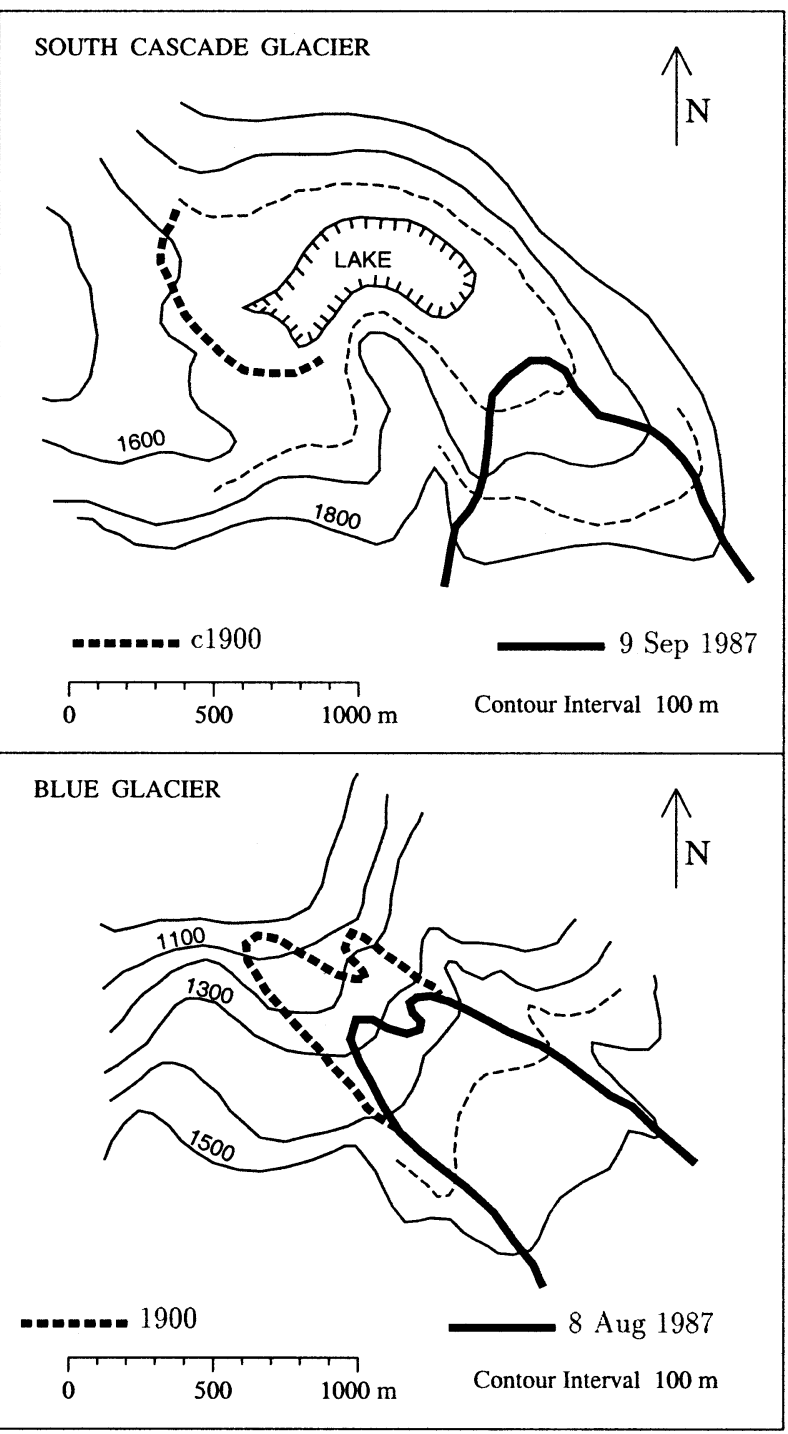

Fig. 11. Proglacial topography and terminus profiles of South Cascade Glacier for 1900 (Miller, 1969) and 1987 (Krimmel, 2000) and of Blue Glacier for 1900 (LaChapelle, 1965) and 1987. In the mid-1950s the terminus of South Cascade Glacier was in the middle of the lake (Miller, 1969). LaChapelle (1965, fig. 3) estimated the thickness of Blue Glacier in 1900 to have been about $80 \mathrm{~m}$ at the location of the 1987 terminus.

in elevation between the two 1900 termini was much greater. The response to warming following the Little Ice Age was faster at Blue Glacier because its lower lobe was thinner and ablation at its lower-elevation terminus was more strongly negative than at South Cascade Glacier.

\section{CONGLUSIONS}

The standard error ( 0.24 mw.e.) of the modeled South Cascade Glacier winter balance is $<10 \%$, which is the same order as the observational error. The strong correlation between its net balance and winter balance $(r=+0.79)$ allows a reasonable estimate of the net balance ( $\mathrm{rms} 0.53 \mathrm{~m}$ w.e.). For any glacier, correlations of net balance with each of the seasonal balances, winter and summer, depend on only two quantities: the correlation between the two seasonal balances and the ratio of their standard deviations. The model could be used to extend the South Cascade Glacier mass-balance series back to 1948, when the National Weather Service began regular upper-air measurements of wind, humidity and tempera- 
ture. The model could also be used to predict how the mass balance might change under possible future climate scenarios from global circulation models.

Analyses of vertical profiles of the net balance at South Cascade Glacier indicate that adjusting the average profile by separate balance differentials provides a much better representation of profiles for individual years than does adjusting it by separate altitude differentials. Because air temperature is strongly related to altitude, separate altitude adjustments might yield a better representation of balance profiles on glaciers where mass-balance variations are dominated by variations in temperature rather than in precipitation.

The mass balance of a glacier in equilibrium with its climate is zero. It is likely, for instance, that the mass balance of Blue Glacier was near zero during the Little Ice Age, just as it has been over the past 40 years. Published values of glacier average mass balance describe the effect of climate on a glacier of varying topography, so that knowledge of the topography history is needed to extract information about the climate. Mass-balance values averaged over the topography of a shrinking glacier, for example, will be more positive than values averaged over a fixed topography.

South Cascade Glacier has been more out of balance than Blue Glacier over the past 40 years, presumably because it is still adjusting to the climate since the Little Ice Age. Observed differences in behavior over that period are caused mainly by differences in past geometry forced by basin topography, rather than by differences of climate between the two locations. In contrast, the mass balance has been similarly affected by recent warming and drying at both glaciers, and both are now well out of equilibrium with the present climate.

\section{ACKNOWLEDGEMENTS}

This work was funded from the U.S. National Science Foundation grant ATM-9530691 and NASA grant 1215388. It was possible because of the prodigious accomplishment of U.S. Geological Survey researchers, principally M. F. Meier, A. S. Post, W. V. Tangborn and R. M. Krimmel, in founding and maintaining the South Cascade Glacier program, and because of Krimmel's superb documentation of the collected data. We thank Scientific Editor M. van den Broeke and two reviewers for their attention to this paper and we thank H. Greenberg for assistance with Figure 1.

\section{REFERENCES}

Armstrong, R. L. 1989. Mass balance history of Blue Glacier, Washington, U.S.A. In Oerlemans, J., ed. Glacier fluctuations and climatic change. Dordrecht, etc., Kluwer Academic Publishers, 183-192.

Bevington, P. R. 1969. Data reduction and error analysis for the physical sciences. New York, McGraw-Hill.

Conway, H., L. A. Rasmussen and P. Hayes. 1995. On the use of radiosondes to model glacier ablation. Ann. Glaciol., 21, 245-250.

Conway, H., L. A. Rasmussen and H.-P. Marshall. 1999. Annual mass balance of Blue Glacier, U.S.A.: 1955-97. Geogr. Ann., 81A(4), 509-520.

Dyurgerov, M. B. and M. F. Meier. 1999. Analysis of winter and summer glacier mass balances. Geogr. Ann., 81A(4), 541-554.

Dyurgerov, M. B., G. I. Ol'shanskiy and N.V. Prokhorova. 1989. Izmenchivost'akkumulyatsii i ablyatsii gornykh lednikov [Variability of accumulation and ablation of mountain glaciers]. Mater. Glyatsiol. Issled. 65, 92-102.

Ebbesmeyer, C. C., D. R. Cayan, D. R. McLain, F. H. Nichols, D. H. Peterson and K. T. Redmond. 1991. 1976 step in the Pacific climate: forty environmental changes between 1968-1975 and 1977-1984. In Betancourt, J. L. and V. Tharp, eds. Proceedings of the 7th Annual Pacific Climate (PACLIM) Workshop, 10-13 April 1990, Asilomar, California. Sacramento, CA, California Department of Water Resources, 129-141. (Interagency Ecological Studies Program Technical Report 26.)

Greuell, W. 1992. Hintereisferner, Austria: mass-balance reconstruction and numerical modelling of the historical length variations. 7. Glaciol., 38(129), 233-244.

Hodge, S. M. 1979. Direct measurement of basal water pressures: progress and problems. f. Glaciol., 23(89), 309-319.

Hodge, S. M., D. C. Trabant, R. M. Krimmel, T. A. Heinrichs, R. S. March and E. G. Josberger. 1998. Climate variations and changes in mass of three glaciers in western North America. F. Climate, 11 (9), 2161-2179.

Krimmel, R. M. 1993. Mass balance, meteorological, and runoff measurements at South Cascade Glacier, Washington, 1992 balance year. U.S. Geol. Surv. Open File Rep. 93-640.

Krimmel, R. M. 1994. Runoff, precipitation, mass balance, and ice velocity measurements at South Cascade Glacier, Washington, 1993 balance year. U.S. Geol. Surv. Water-Resour. Invest. Rep. 94-4139.

Krimmel, R. M. 1995. Water, ice, and meteorological measurements at South Cascade Glacier, Washington, 1994 balance year. U.S. Geol. Surv. Water-Resour. Invest. Rep. 95-4162.

Krimmel, R. M. 1996. Water, ice, and meteorological measurements at South Cascade Glacier, Washington, 1995 balance year. U.S. Geol. Surv. Water-Resour. Invest. Rep. 96-4174.

Krimmel, R. M. 1997. Water, ice, and meteorological measurements at South Cascade Glacier, Washington, 1996 balance year. U.S. Geol. Surv. Water-Resour. Invest. Rep. 97-4143.

Krimmel, R. M. 1998. Water, ice, and meteorological measurements at South Cascade Glacier, Washington, 1997 balance year. U.S. Geol. Surv. Water-Resour. Invest. Rep. 98-4090.

Krimmel, R. M. 1999. Water, ice, meteorological and speed measurements at South Cascade Glacier, Washington, 1998 balance year. U.S. Geol. Surv. Water-Resour. Invest. Rep. 99-4049.

Krimmel, R. M. 2000. Water, ice, meteorological and speed measurements at South Cascade Glacier, Washington, 1986-1991 balance years. U.S. Geol. Surv. Water-Resour. Invest. Rep. 00-4006.

LaChapelle, E. R. 1958. USNC-IGY Glaciology Project 4.3, Blue Glacier. Seattle, WA, University of Washington. Department of Meteorology and Climatology. (Preliminary Report.)

LaChapelle, E. R. 1965. The mass budget of Blue Glacier, Washington. F. Glaciol., 5(41), 609-623.

McCabe, G. J., Jr and A. G. Fountain. 1995. Relations between atmospheric circulation and mass balance of South Cascade Glacier, Washington, U.S.A. Arct. Alp. Res., 27(3), 226-233.

McClung, D. M. and R. L. Armstrong. 1993. Temperate glacier time response from field data. F. Glaciol., 39(132), 323-326.

Meier, M. F. and W.V. Tangborn. 1965. Net budget and flow of South Cascade Glacier, Washington. f. Glaciol., 5 (41), 547-566.

Miller, C. D. 1969. Chronology of Neoglacial moraines in the Dome Peak area, North Cascade Range, Washington. Arct. Alp. Res., 1(1), 49-66.

Minobe, S. 1997. A 50-70 year climatic oscillation over the North Pacific and North America. Geophys. Res. Lett., 24(6), 683-686.

Oerlemans, J. 1992. Climate sensitivity of glaciers in southern Norway: application of an energy-balance model to Nigardsbreen, Hellstugubreen and Alfotbreen. F. Glaciol., 38(129), 223-232.

Oerlemans, J. 1993. A model for the surface balance of ice masses: Part 1. Alpine glaciers. Z. Gletscherkd. Glazialgeol., 27-28, 1991-1992, 63-83.

Oerlemans, J. and N. C. Hoogendoorn. 1989. Mass-balance gradients and climatic change. F. Glaciol., 35(121), 399-405.

Rasmussen, L. A., H. Conway and P. S. Hayes. 2000. The accumulation regime of Blue Glacier, U.S.A., 1914-96. F. Glaciol., 46(153), 326-334.

Rasmussen, L. A., H. Conway and P. S. Hayes. 2001. Estimating Olympic Peninsula precipitation from upper-air wind and humidity. 7. Geophys. Res., 106(D2), 1493-1501.

Ross, R. J., J. Otterman, D. O’C. Starr, W. P. Elliott, J. K. Angell and J. Susskind. 1996. Regional trends of surface and tropospheric temperature and evening-morning temperature difference in northern latitudes: 1973-93. Geophys. Res. Lett., 23(22), 3179-3182.

Trenberth, K. E. 1990. Recent observed interdecadal climatic change in the Northern Hemisphere. Bull. Am. Meteorol. Soc., 71, 988-993.

United States Navy. 1966. Selected level temperatures and dew points for the Northern Hemisphere. Washington, DC, U.S. Navy. Chief of Naval Operations. (Document NAVAIR 50-1C-52. 